\title{
E-Recruitment as a Strategy for Informal Networking: A Case Study of Mobilink
}

\author{
Muhammad Arslan (Corresponding Author) Rashid Zaman \\ Bahria University Islamabad, Pakistan PO box 44000, E-8, Islamabad, Pakistan \\ Email: MuhammadArslan73@gmail.com
}

\begin{abstract}
E-recruitment strategy is necessary to attract the potential employees to better equip the organization with competent workforce. E-recruitment helps to get the informal networks for the organization. These informal networks support the organization in form of employee's clarity of their roles, which increases the organizational knowledge of employees to perform their tasks efficiently. It increases the satisfaction of employees which in result will increase the commitment of employees for organization in long run. A case study of Mobilink, a repudiated telecommunication company, is conducted to get the implication of e-recruitment strategy that either it is beneficial for the organization or not. The survey method was employed for data gathering. The results have strong support for the long run benefits, for Mobilink, of adopting e-recruitment strategy.
\end{abstract}

Keywords: E-Recruitment, Mobilink, Employees, Informal Networks

\section{Introduction}

Recruitment is the basis for an organization to create and then continually recreate itself. It involves the workforce of an organization who are directly involved in the ecology of organizations. When individuals arrive, grow, develop and departure, it shows the success or failure of a recruiter who recruited them. Recruitments are particular activities carried out by organization with the main objective of finding the real objectives of organization by finding the competent workforce for the organization (Breaugh\& Starke, 2000).

E-recruitment is necessary because employers must have effective means of attracting appropriate employees. E-recruitment includes both corporate website and commercial boards. Under corporate website, social networking includes face book, LinkedIn, and twitter.

To get competent workforce is a challenge for recruiter of an organization. So HR department of an organization is always adaptive to innovations that can better cope the requirements of an organization regarding to its workforce. E-recruitment is one of the innovations of mid of 1990's that were used to equip an organization with competent workforce who can adopt itself with rapid changing environment. Organizations adopt this strategy as an innovation after channelizing the innovation to the social system of an organization that how they react to the innovation, if it will help to get better results and implications, organizations will be more likely to opt this strategy.

Web 1.0 is also a form of e-recruitment which includes job boards, career websites and recruitment systems (Parry \& Tyson, 2008), While web 2.0 includes blogs and online informal and social networking. Web 1.0 is essential for recruitment transactions but in highly competitive environment web 1.0 becomes insufficient and web 2.0 not only helps for the good reputation of recruiter and organization but will also be helpful to find competent individuals for better results of the organization and to cope the rapid changing environment also. It can also be used for the firm as a source of outsourcing the selection of individual and applicants and also for the decentralization of recruitment.

E-recruitment is a strategy for an organization, by using modes of corporate websites and commercial boards, not only to get the competent work force to meet the objectives of the organization but to develop a confidence for the employees which will increase the informal networking of an organization. This informal networking will help not only the existing employees but also the coming employees in organization that what organization is expecting to play a competent role beneficial for organization and for upcoming workforce. So, E-recruitment will not only help for informal networking but also will increase the knowledge of employees regarding organization. Organizational knowledge will make role of employees clear that will help the organization for mutual development of workforce which not only in short run but also in long run will be helpful for the organization to the gradual ecology of the organization. When recruiter according to the competencies and qualification will assign the tasks and duties to the employees it will increase the satisfaction level of the employees. When employees will be satisfied by the organization and by the tasks assigned to them it in result will increase the commitment of the employees in terms of their performance that ultimately will help to retain the employees in long run.

The study is trying to show e-recruitment as a strategy for Mobilink, a repudiated telecommunication company who is also using e-recruitment strategy for the long run attainment of informal networking. This informal networking ultimately will help the applicants and employees for their role clarity, mutual development, job satisfaction, organizational knowledge, and firm commitment. At this level the firm or organization will be 
sure that its HR department has been successful in retention of the employees in long run which is actually the main purpose of every recruitment department (Smith, 1998). To find the application of this statement, a survey is conducted whose result will be shown in coming chapters, first providing the evidence through literature review.

\section{Literature Review}

Smith, (1988) in his studies focused that the basic purpose of recruitment is to retain the employees not to be fired after that because it also involves the cost for the organization so he conducted his studies for student that institutions want to retain the employees after their recruitment. And then to find out the ways that how can these goals be achieved.

In 1993, Krackhardt, D., and R. Hanson conducted this study. According to their network analysis, if the formal networks are the Skelton of an organization, then it will be the central system deriving the collective action and process of the whole business unit. These networks also help to understand the roles of these employees in the organizations.

Lee, R. (1994), in his article demonstrated that recruitment is the process of creating and continuously re-creating the organization. To make this process successful, it is necessary for the labor force to be more skillful and adaptive to understand the core responsibility assigned by that organization. Workforces also have some pressures on their performance regarding their security and flexibility. If organization will make them sure that they are hired for a long term period they can perform their duties well. And if organization will not be providing security to their employees, it must provide trainings to their employees for the security of their future in market. When organization seems to be on a track unmatched with the goals of the organization all blame will be on employees but the actual problem occurred when the employees were empowered to work in that organization during the process of recruitment. So recruiter will always see the core competencies of the recruiter and then will hire him otherwise the person will be rejected for having limited competency. Organization evolution is a natural phenomenon when people come to an organization and have ability to adapt according to the environment not only for the sake of their own survival but for the organization also because an organization evolve slowly when individuals arrive, grow, develop and departure. Recruitment is the process of dealing challenges and diversity. And an organization want to be professionally successful it must have a number of fair people who think differently for organization in a radical way. Four dilemmas such as flexibility/security, control/empowerment, competence/learning, and comfort/challenge were discussed in this paper. So recruitment is an essential process to develop the ecology of an organization in terms of its workforce or employees.

Daniel M. Cable and Daniel B. Turban(2001), in their article demonstrated that job seekers want to evaluate the organization by getting knowledge about the recruiter of the organization and if they will use this information, the applicant will be a useful asset for the organization depending upon the source that what mode he is using to get information and in this way he will be able to get competency for organizational goals in a good manner and it will also help the applicant either he should join the organization after recruitment or not, as the beliefs of people determine the behavior of the people similarly depending upon the knowledge about recruiter and organization will determine the applicant behavior about either he will join the organization or not.

Elizabeth Whole Morrison (New York University) was conducted this study in Dec 2002. The structure of the newcomers' friendship networks related to their social integration and organizational commitment. By linking socialization outcomes to social network structure, this study sheds new light on the role of relationships in newcomer learning and incorporation.

Dahl, M., and Pedersen, C., conduct this study in 2002, here in this paper defines how the hypothetical donations in dispute that knowledge is diffused through informal contacts have been censured recently by scholars stating that agents will not disclose firm specific knowledge to outside agents, because of faithfulness to the firm. They argue that employees will only exchange more general knowledge of low value, which will not have shortcomings for their firms. Though, we show in this paper that more detailed information is dim. Even specific knowledge on new products, which is possible to be very firm specific and which the firms are likely to want to guard from participants. A large share of the engineers asked received knowledge from their informal contact, which they value to be of intermediate importance for their own work. This tells us that the informal contacts are an importance source of evidence for the engineer in this collection.

Marra, M., conducted this exploratory study in 2011 . The exploratory study suggests that competences and capabilities are often accumulated in secondary nodes. Such peripheral nodes play an important role in fostering the knowledge transfer within the organization and to create important relations with external collaborators. For the same reason a bottom-up knowledge governance emerged as a significant component in enhancing the knowledge transfer between actors within the firm and between the firm and its external partners, accelerating its ability to innovate and learn. The bases for a successful innovation process are interactions and the continuous feedback among activities within the same firm and between the firm's external sources of knowledge. They represent the opportunity to have access to knowledge resources unavailable internally. The 
development of firm specific knowledge resources required key employees; such key employees have been identified to study their role in the firm.

The research study conducted by Christine Greenhow in (2011), offered the two themes that are based on a choice appraisal of the research literature as well as the author's surveys of fresh people's online social networking practices of Face book and MySpace, two obviously happening, youth-initiated sites, as well as in an online social networking request intended for ecological science training and community action. Author elegant that how social media, such as social network sites, currently support informal learning may develop one's aptitude to build current operative social media-enabled surroundings for additional formal learning objectives.

Girard, A. and Fallery, B. (2011), in their studies focused that e-recruitment, at first stage just works as a transaction for organization but latter on results in achieving the informal social networks to expand the competency of that particular organization in form of competent employees with diversified cultures and experiences to cope with the challenges of rapid changing environments. Researchers have categorized the activities of e-recruitment and their sequential effects in two forms and named it as WEB 1.0 and WEB 2.0. Web 1.0 just includes the job boards, corporate websites, and recruitment systems, while web 2.0 results in online informal networking that will be helpful and advantageous for the organization. Web 1 is essential for recruitment transactions but in highly competitive environment this web 1.0 becomes insufficient while web 2.0 is used as to develop employees branding and reputation. Web 2.0 makes it possible to make new relationships with applicants. So, this tool is also used for decentralization of recruitment responsibilities or development of outsourcing. It in turn will increase the commitment of the employees.

\section{Conceptual Framework}

This research is trying to explore the significance of e-recruitment as a strategy in Mobilink, telecommunication corporation, which is widely adopting this strategy, to increase their informal networking for the retention of employees in terms of their role clarity, job satisfaction, organizational commitment, organizational knowledge, (Morrison, E., 2011).

Hypothesis 1: Informal networking is positively associated with E-recruitment strategy.

E-recruitment as a strategy has the major objective of achieving the competent workforce but to get in touch with competent employees is a challenging task in this era of rapid changing environment. Web 1.0 and web 2.0 are the tools under e recruitment strategy to have a reach to the competent individual for that particular organization positive informal networking, (Parry \&Tisson, Leader, Hamilton, \& Cowan, 2008). It will help organization in terms of cost effectiveness, access to more job seekers, ability to target required target employees, access to applicants with technical capabilities, quick response time of respondents and it is very easy to use, (Galanaki, 2002; Zusman\&Landia, 2002).

Hypothesis 2: Role clarity, organizational knowledge, job satisfaction,and organizational commitment are positively associated with informal networking.

All the dependent variables are correlated with each other. One component will help to achieve the better results of others, (Dahl \& Pederson). Because organization knowledge will be best achieved through informal networking which in result will increase the satisfaction level of employees which in result will work for the retention of employees in organization for a long term period.

It is the benefits in terms of employees compensation, health benefits of working employees; stable organizational characteristics, balanced work life, expected future opportunities regarding career, respected job to satisfy the employees ego, working place, benefits after retirement and morals that attract the competent work force to join that organization with more commitment and loyalty but this attraction can easily be communicated on wider range through tools of web 1.0 and web 2.0, which in result will not only increase the social networking but also will help to increase the commitment of employees in terms of their retention, (Smith, 1988).

\section{Methodology}

A case study method is adopted and the workforce of three categories is included in survey sample which includes HR officers, employees and managers of Mobilink. Survey method is used to collect the data which includes semi structured interviews from HR Managers and questionnaires from managers and employees of the organization who have been hired in company through e-recruitment and how they helped to get informal networking for the organization in terms of upcoming employees and workforce of the organization.

Survey method have been adopted which includes the in depth semi structured interviews of HR officers of Mobilink to get the insight of too much extent the organization is using the e-recruitment as a strategy to enhance their competent workforce by providing them the bridge of attraction through means of social networking which in positive sense will enhance the capabilities of employees regarding the clarity of their role, their commitment through channelized information and in long run retention of their employees.

For analysis of data, descriptive technique is used. So that the results of questionnaires and interviews can best be analyzed and explained to show the impact of e-strategy on informal networking of organization and 
at the end retention of employees in long run. For mathematical presentation bar chart is used.

Questions included in semi structured interviews are listed in table;

Either company is using Online recruitment or not?

What is the reason behind the adoption of this innovation?

What is their perception of advantages and disadvantages?

\section{Informal networking:}

While the questions included for the liker scale analysis are as followed;

Support of e-recruitment for acquiring informal networking within the organization

Informal networking helpful for more effective expertise in form of employees

Positive response of employees towards e-recruitment because of increasing competition

You increased the informal networks after joining the organization

\section{Organizational Knowledge}

You get the job because you are potential to get informal networks for the organization

Informal networks provided by you have influence on their perception regarding the commitment for the organization.

\section{Role Clarity}

Informal networks provided by you have influence regarding the role clarity of employees.

Informal networks help them to have complete knowledge about duties, what they are expected to do for the organization

\section{Job Satisfaction}

Employees coming through informal networking are satisfied at the time of hiring about all the working conditions of the organization

Employees feeling free to move in office during the working hours with friendly environment

This commitment was just result of strong networks

\section{Organizational Commitment}

You provided any sort of informal network to organization after your hiring

These informal networks helped you to acquire knowledge about competitors for your promotion or benefits

These informal networks helped you to acquire knowledge about competitors for the advantage of organization.

These informal networks increased the commitment of employees for long run.

\section{Results}

Most of the employee's behavior to the questionnaires was very supportive for the e-recruitment strategy. The questionnaires filled by the managers and all the young employees working in the organization. The company is using corporate websites and commercial boards for the capable and potential employees for the organization. Each time those employees are preferred for the organization who are referred through the working employees networks because such employees are considered more potential for the organization who already know what the company is going to expect to them and what tasks they are going to perform so in each case, e-recruitment strategy always help the HR department and overall organization to hire those people who already have knowledge and knowhow of organization. Informal networks have created friendly environment for the employees during working hours which in turn is increasing the satisfaction of employees. During interviews and filling the questionnaires most of the employees were asked either they are satisfied by Mobilink or not? The answer was yes because organization trusts us and we are doing the assigned tasks in friendly environment by providing potential networks to organization. So, Mobilink is retaining the employees for long run by using an effective e-recruitment strategy in terms of employee's commitment.

Following are the tables providing the evidences for support of results by encoding the frequency of liker scale.

Table 1:

\section{Support for informal networking}

\begin{tabular}{|ll|l|l|l|l|}
\hline & Frequency & Percent & Valid Percent & $\begin{array}{l}\text { Cumulative } \\
\text { Percent }\end{array}$ \\
\hline Valid disagree & 7 & 14.0 & 14.0 & 14.0 \\
& slightly agree & 15 & 30.0 & 30.0 & 44.0 \\
& agree & 13 & 26.0 & 26.0 & 70.0 \\
strongly agree & 15 & 30.0 & 30.0 & 100.0 \\
Total & 50 & 100.0 & 100.0 & \\
\hline
\end{tabular}


Table 2:

Influence the employees perception of commitment

\begin{tabular}{|ll|l|l|l|l|}
\hline & & Frequency & Percent & Valid Percent & Cumulative Percent \\
\hline Valid & disagree & 3 & 6.0 & 6.1 & 6.1 \\
& slightly agree & 15 & 30.0 & 30.6 & 36.7 \\
& agree & 23 & 46.0 & 46.9 & 83.7 \\
& strongly agree & 8 & 16.0 & 16.3 & 100.0 \\
& Total & 49 & 98.0 & 100.0 & \\
Missing & System & 1 & 2.0 & & \\
& Total & 50 & 100.0 & & \\
\hline
\end{tabular}

Table 3:

Clear about their expected duties

\begin{tabular}{|ll|l|l|l|l|}
\hline & Frequency & Percent & Valid Percent & Cumulative Percent \\
\hline Valid & disagree & 2 & 4.0 & 4.0 & 4.0 \\
& slightly agree & 16 & 32.0 & 32.0 & 36.0 \\
& agree & 13 & 26.0 & 26.0 & 62.0 \\
strongly agree & 19 & 38.0 & 38.0 & 100.0 \\
Total & 50 & 100.0 & 100.0 & \\
\hline
\end{tabular}

Table 4:

Satisfied about working conditions

\begin{tabular}{|c|c|c|c|c|c|}
\hline & & Frequency & Percent & Valid Percent & Cumulative Percent \\
\hline \multirow[t]{5}{*}{ Valid } & disagree & 5 & 10.0 & 10.0 & 10.0 \\
\hline & slightly agree & 18 & 36.0 & 36.0 & 46.0 \\
\hline & agree & 17 & 34.0 & 34.0 & 80.0 \\
\hline & strongly agree & 10 & 20.0 & 20.0 & 100.0 \\
\hline & Total & 50 & 100.0 & 100.0 & \\
\hline
\end{tabular}

Table 5:

Satisfaction of employees due to strong networks

\begin{tabular}{|l|l|l|l|l|l|}
\hline & & Frequency & Percent & Valid Percent & Cumulative Percent \\
\hline \multirow{6}{*}{ Valid } & Disagree & 3 & 6.0 & 6.0 & 6.0 \\
\cline { 2 - 6 } & slightly agree & 14 & 28.0 & 28.0 & 34.0 \\
\cline { 2 - 6 } & Agree & 16 & 32.0 & 32.0 & 66.0 \\
\cline { 2 - 6 } & strongly agree & 17 & 34.0 & 34.0 & 100.0 \\
\cline { 2 - 6 } & Total & 50 & 100.0 & 100.0 & \\
\hline
\end{tabular}


Table 6:

Increased commitment of employees

\begin{tabular}{|ll|l|l|l|l|}
\hline & Frequency & Percent & Valid Percent & Cumulative Percent \\
\hline Valid & strongly disagree & 2 & 4.0 & 4.0 & 4.0 \\
& disagree & 5 & 10.0 & 10.0 & 14.0 \\
slightly agree & 14 & 28.0 & 28.0 & 42.0 \\
agree & 22 & 44.0 & 44.0 & 86.0 \\
strongly agree & 7 & 14.0 & 14.0 & 100.0 \\
Total & 50 & 100.0 & 100.0 & \\
\hline
\end{tabular}

All the tables are presenting six independent variables which have greater impact of e-recruitment strategy in form of informal networking for the organization, role clarity, organizational knowledge, job satisfaction, mutual development and commitment of employees which is not only beneficial for the employees coming through e-recruitment but for the organization in long run in terms of their long run retention. Following are the Bar charts presenting the support for e-recruitment strategy by telling that how much they are beneficial for the organization in terms of creating informal networks for the organization.

\section{support for informal networking}

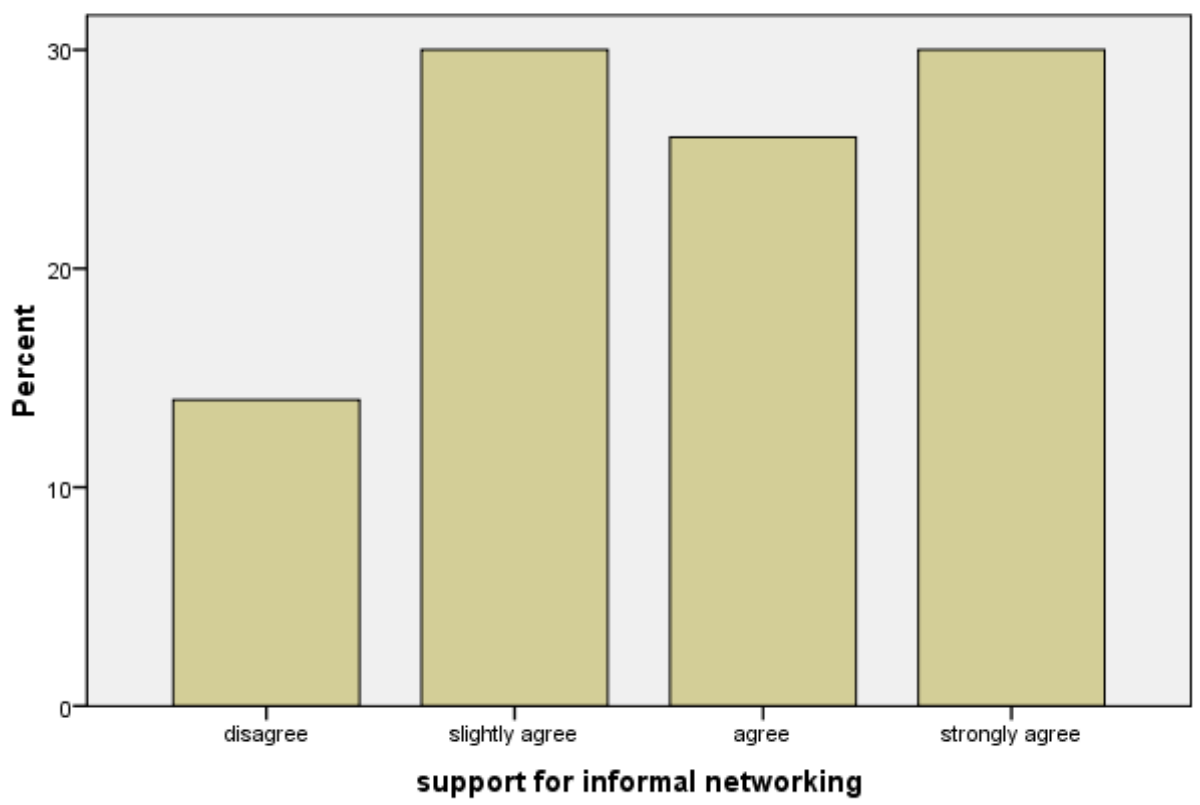

The employees of Mobilink were strongly agree that e-recruitment strategy has increased and support the informal networks for the organization. 
influence the employees perception of comittment

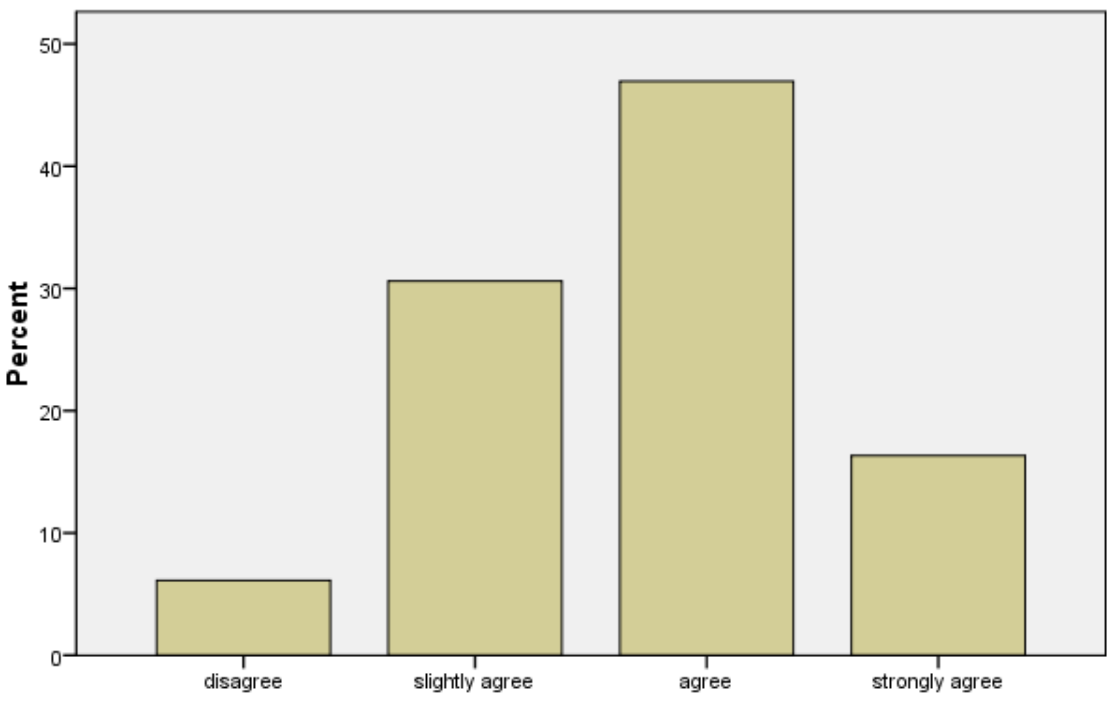

influence the employees perception of comittment

Employees that came in the organization through informal networks were more committed to the organization in terms of policies and their implication.

satisfaction of employees due to strong networks

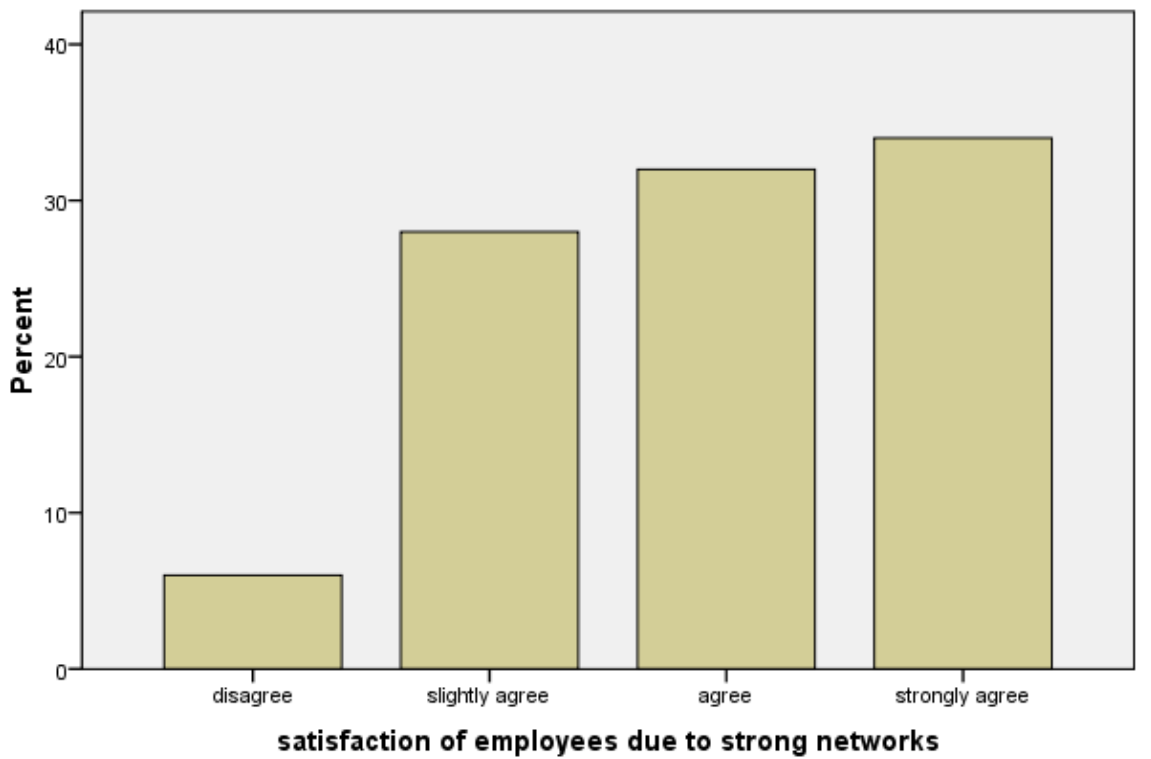

Employees coming through e-recruitment were more satisfied in terms of their role clarity, organizational knowledge and mutual development. The overall results of the study are positively favoring the adoption of e-recruitment strategy for getting the more potential employees for the organization in this competition world.

\section{References}

Tipper, J. (2004), How to increase the diversity through your recruitment practices. Industrial and Commercial Training, 36, 158-161.

Doherty, R. (2010), Getting social with recruitment. Journal of Strategic HR review,9, 11-15.

Lee, R. (1994), Recruitment in context. Journal of Librarian Career Development, 2, 2-7.

Girard, A., and Fallerly, B. (2011), E-recruitment from transaction based practices to relationship based approaches. Journal of Advance Series in Management.Ch. 8, 143-158.

Parry, E., and Olivas, M. R. (2011), Drivers of the adoption of online recruitment_an analysis using innovation attributes from diffusion of innovation theory. Journal of Advance Series in Management. Ch. 9, 159-174. 
Cable, D. M., \& Turban, D. B. (2001), Establishing the dimensions, sources, and value of job seeekers employer knowledge during recruitment. Research in Personnel and Human Resource Management. 20, 115-163.

Jones, S., \& Ahmad, A. (2011), The perception of employer value propositions and the contrast between Dutch and Chinese graduates_a case study of TNT. 1, 1-9.

Gullickson, A. R., \& Tresslor, G.R. (2002), Recruitment and Retention, Advances in Programme Evaluation. 9, 131 161.

Dahl, M., \& Pedersen, C. O. R. (2002), Knowledge flows through informal contacts in industrial clusters: Myths or realities? Danish Research Unit for Industrial Dynamics.

Marra, M. (2011), The relation between firm's informal network, knowledge transfer and innovation.

Krackhardt, D., \& Hanson, J. R. (1993), Informal network: the company behind the chart. Harvard Business Review.

Morrison, E. W. (2002). Newcomers' relationships: the role of social network ties during socialization. Academy of Management Journal. 45, 1149-1160.

Greenhow, C. (2011). Online social networking and learning. 19, 4-12.

\section{Appendix 1}

Assessing the E-Recruitment strategy's Impact on the Informal networks in Mobilink

The purpose of this survey is to assess the effect of e-recruitment on informal networks for Mobilink. The erecruitment effect will be measured by using three dependent variables, informal networking, role clarity, job satisfaction, job commitment and organizational knowledge. The focus group of this research is the managers and employees of Mobilink, Islamabad.

Gender. Age Designation.

Department

\section{1 = Strongly Disagree, 2 = Disagree, $\quad 3=$ Slightly Agree, $4=\quad$ Agree, $5=$ Strongly Agree}

\section{E-Recruitment Strategy}

Which is refers to the adoption of electronic sources to hire the force or employees of the organization which in turn will increase the informal network of organization

\begin{tabular}{|c|c|c|c|c|c|}
\hline Informal Networking & 1 & 2 & 3 & 4 & 5 \\
\hline $\begin{array}{l}\text { Support of e-recruitment for acquiring informal networking within the } \\
\text { organization }\end{array}$ & & & & & \\
\hline $\begin{array}{l}\text { Informal networking helpful for more effective expertise in form of } \\
\text { employees }\end{array}$ & & & & & \\
\hline $\begin{array}{l}\text { Positive response of employees towards e-recruitment because of increasing } \\
\text { competition }\end{array}$ & & & & & \\
\hline You increased the informal networks after joining the organization & & & & & \\
\hline
\end{tabular}

\begin{tabular}{|c|c|c|c|c|c|}
\hline Organizational Knowledge & 1 & 2 & 3 & 4 & 5 \\
\hline $\begin{array}{l}\text { You get the job because you are potential to get informal networks for the } \\
\text { organization. }\end{array}$ & & & & & \\
\hline $\begin{array}{l}\text { Informal networks provided by you have influence on their perception } \\
\text { regarding the commitment for the organization. }\end{array}$ & & & & & \\
\hline
\end{tabular}

\begin{tabular}{|c|c|c|c|c|c|}
\hline Role Clarity & 1 & 2 & 3 & 4 & 5 \\
\hline $\begin{array}{l}\text { Informal networks provided by you have influence regarding the role clarity } \\
\text { of employees. }\end{array}$ & & & & & \\
\hline $\begin{array}{l}\text { Informal networks help them to have complete knowledge about duties, what } \\
\text { they are expected to do for the organization. }\end{array}$ & & & & & \\
\hline
\end{tabular}

\begin{tabular}{|c|c|c|c|c|c|}
\hline Job Satisfaction & 1 & 2 & 3 & 4 & 5 \\
\hline $\begin{array}{l}\text { Employees coming through informal networking are satisfied at the time of } \\
\text { hiring about all the working conditions of the organization. }\end{array}$ & & & & & \\
\hline $\begin{array}{l}\text { Employees feeling free to move in office during the working hours with } \\
\text { friendly environment }\end{array}$ & & & & & \\
\hline This commitment was just result of strong networks. & & & & & \\
\hline
\end{tabular}




\begin{tabular}{|c|c|c|c|c|c|}
\hline Organizational Commitment & 1 & 2 & 3 & 4 & 5 \\
\hline You provided any sort of informal network to organization after your hiring. & & & & & \\
\hline $\begin{array}{l}\text { These informal networks helped you to acquire knowledge about competitors } \\
\text { for your promotion or benefits. }\end{array}$ & & & & & \\
\hline $\begin{array}{l}\text { These informal networks helped you to acquire knowledge about competitors } \\
\text { for the advantage of organization. }\end{array}$ & & & & & \\
\hline $\begin{array}{l}\text { These informal networks increased the commitment of employees for long } \\
\text { run. }\end{array}$ & & & & & \\
\hline
\end{tabular}

\section{Appendix 2}

Table 1.1

1 = Strongly Disagree, 2 = Disagree,

$3=$ Slightly Agree, $4=\quad$ Agree, $5=$ Strongly Agree

\begin{tabular}{|l|l|l|l|l|l|}
\hline Behavior/Competency & $\mathbf{1}$ & $\mathbf{2}$ & $\mathbf{3}$ & $\mathbf{4}$ & $\mathbf{5}$ \\
\hline support for informal networking & 0 & 14 & 30 & 26 & 30 \\
\hline expertise in form of employees & 2 & 6 & 34 & 36 & 22 \\
\hline positive response due to competition & 0 & 4 & 32 & 42 & 22 \\
\hline increase in informal networks & 0 & 10 & 22 & 42 & 26 \\
\hline potential for getting networks for organization & 0 & 2 & 38 & 40 & 18 \\
\hline influence the employees perception of commitment & 0 & 6 & 30 & 46 & 16 \\
\hline influence to make clear the roles of employees & 2 & 2 & 28 & 42 & 26 \\
\hline clear about their expected duties & 0 & 4 & 32 & 26 & 38 \\
\hline satisfied about working conditions & 0 & 10 & 36 & 34 & 20 \\
\hline feel free to move in office during working hours & 4 & 8 & 26 & 38 & 24 \\
\hline satisfaction of employees due to strong networks & 0 & 6 & 28 & 32 & 34 \\
\hline number of informal networks provided to organization & 0 & 2 & 18 & 38 & 42 \\
\hline Help to get knowledge about competitors for personal benefit & 0 & 2 & 32 & 38 & 28 \\
\hline helping to get knowledge about competitors for organization & 0 & 12 & 24 & 36 & 28 \\
\hline increased commitment of employees & 4 & 10 & 28 & 44 & 14 \\
\hline
\end{tabular}


The IISTE is a pioneer in the Open-Access hosting service and academic event management. The aim of the firm is Accelerating Global Knowledge Sharing.

More information about the firm can be found on the homepage:

http://www.iiste.org

\section{CALL FOR JOURNAL PAPERS}

There are more than 30 peer-reviewed academic journals hosted under the hosting platform.

Prospective authors of journals can find the submission instruction on the following page: http://www.iiste.org/journals/ All the journals articles are available online to the readers all over the world without financial, legal, or technical barriers other than those inseparable from gaining access to the internet itself. Paper version of the journals is also available upon request of readers and authors.

\section{MORE RESOURCES}

Book publication information: http://www.iiste.org/book/

\section{IISTE Knowledge Sharing Partners}

EBSCO, Index Copernicus, Ulrich's Periodicals Directory, JournalTOCS, PKP Open Archives Harvester, Bielefeld Academic Search Engine, Elektronische Zeitschriftenbibliothek EZB, Open J-Gate, OCLC WorldCat, Universe Digtial Library, NewJour, Google Scholar

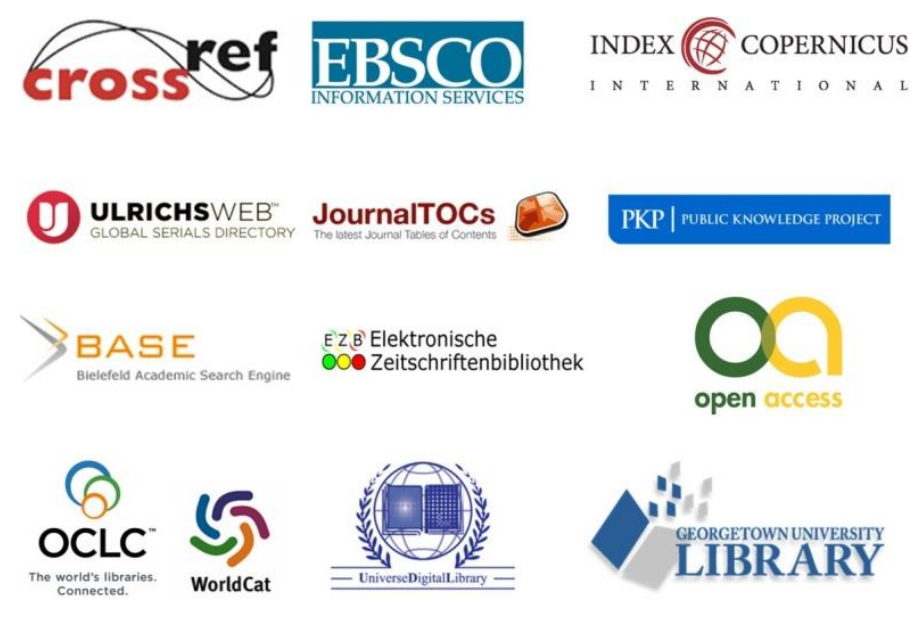

